East African Medical Journal Vol. 80 No. 6 June 2003

PSYCHIATRIC MORBIDITY AMONG CHILDREN AND YOUNG PERSONS APPEARING IN THE NAIROBI JUVENILE COURT, KENYA

H.M. Maru, MBBS (India) MMed (Psych), Consultant Psychiatrist, Deputy Medical Superintendent, Mathari Hospital, Assistant Director of Medical Services, Ministry of Health, P.O. Box 40663, Nairobi, Kenya, D.M. Kathuku, MBChB (Makerere), MMed (Psych) (Nrb), Av Med, Senior Lecturer and D.M. Ndetei, MBChB (Nrb), DPM (Lond), MRCPsych (UK), MD(Nrb), Professor, Department of Psychiatry, College of Health Sciences, University of Nairobi, P.O. Box 19676, Nairobi, Kenya

Request for reprints to: Dr. H.M. Maru, P.O. Box 10139, Nairobi, Kenya

\title{
PSYCHIATRIC MORBIDITY AMONG CHILDREN AND YOUNG PERSONS APPEARING IN THE NAIROBI JUVENILE COURT, KENYA
}

\author{
H.M. MARU, D.M. KATHUKU and D. M. NDETEI
}

\begin{abstract}
Objectives: To estimate the prevalence and pattern of psychiatric disorders among children and young persons appearing in the Nairobi juvenile court, Kenya.

Design: A point prevalence survey.

Setting: The Nairobi Juvenile Court, Kenya.

Subjects: Ninety (sixty-four males and twenty-six females) children and young persons aged 8 to 18 years classified as criminal offenders, group I (60), and those for protection and discipline, group II (30), were selected.

Method: A socio-demographic questionnaire, reporting questionnaire for children (RQC), follow-up interview for children (FIC), present state examination (PSE) and clinical interview were administered to the subjects. International Classification of Diseases, 10th Edition (ICD-10) diagnostic criteria were used.

Results: The crude psychiatric morbidity (CPM) rate was $44.4 \%$. ICD-10 documented psychiatric disorders detected in those with CPM were conduct disorders $45 \%$, mixed disorders of conduct and emotion $20 \%$, emotional disorders with onset specific to childhood $20 \%$, mood disorders $12.5 \%$ and hyperkinetic disorders $2.5 \%$.

Conclusion: This study has shown a high presence of psychiatric morbidity in children and young persons appearing in the Nairobi Juvenile Court. These juveniles need and would benefit from mental treatment as recommended in section 18 of Cap 141 of the laws of Kenya; The Children's and Young Persons Act.
\end{abstract}

\section{INTRODUCTION}

Delinquency comes from the Latin word delinquere "to make mistake". Though not a diagnostic terminology in psychiatric texts, it is an unfortunate term. Russel(1) noted delinquency as a term calling to mind an immediate type: the tough, unruly kid, with no respect for persons, property or society, who makes a practice of mayhem, destruction, stealing and other forms of aggressive antisocial behaviour.

Globally, crime rate is on the rise and most criminals have been shown to have antisocial behaviour. Follow up studies into adult life, of both clinic and nonclinic children, show that antisocial behaviour in childhood is followed by a substantially increased risk of adult criminality. There is increased risk also of marital problems and breakdown, difficulties in parenting, poor job record and unemployment, financial dependency, social alcohol and drug related problems and of mental disorder(2).

Antisocial behaviour has been noted to begin during childhood. Therefore one must focus on its prevention. From an early age any measures that improve the mental health of antisocial children and its families are likely to reduce deviant behaviour(3). Lucien(4) notes that a large proportion of children and adolescents appearing before the courts have no major physical or psychological abnormality. They are simply the victims of adverse external circumstances, characterised by social insecurity or a too low standard of living or a combination of both. Snyder(5) reported from the United States of America an increase in the juvenile courts caseload by $23 \%$ between 1989 and 1993. In Kenya, between 1991 and 1994 the Nairobi Juvenile Court's caseload increased by $21 \%$ (Table 1 ). 
Table 1

Comparison of the number of cases registered at the Nairobi juvenile court from 1981-85 and 1991 upto August 1997

\begin{tabular}{|c|c|c|c|c|c|c|c|c|c|c|c|c|}
\hline Year & 1981 & 1982 & 1983 & 1984 & 1985 & 1991 & 1992 & 1993 & 1994 & 1995 & 1996 & $\begin{array}{l}\text { Aug. } \\
1997\end{array}$ \\
\hline Criminal & 1380 & 1199 & 1435 & 1740 & 1627 & 2153 & 2107 & 2650 & 2528 & $*$ & 2167 & 1357 \\
\hline $\begin{array}{c}\text { Protection \& } \\
\text { discipline }\end{array}$ & 124 & 136 & 47 & 76 & 54 & 175 & 230 & 249 & 284 & 323 & 443 & 457 \\
\hline Total & 1504 & 1335 & 1482 & 1816 & 1681 & 2328 & 2337 & 2899 & 2812 & & 2610 & 1814 \\
\hline
\end{tabular}

* The 1995 register for criminal cases was not available at the juvenile court

The ten most common offences committed by young offenders in Kenya are stealing, assault causing actual bodily harm, breaking into a building and committing felony, housebreaking, stealing by servants, damaging property, indecent assault and possession of cannabis(6). Some of the aetiological factors to delinquency have been documented as: - Genetically inherited characteristics(7), low platelet monoamine oxidase activity(8), high serum triiodothyronine levels(8), extroverts(9), psychiatric morbidity(10,11), brain injury(12), low intelligence quotient(13), epilepsy(14), substance abuse(1) and large families with poor socio-economic support (15). The Nairobi juvenile court is the only permanent juvenile court in Kenya. In other districts of Kenya, the usual courts are converted into juvenile courts whenever a need arises. This court is governed by the Children and Young Persons Act(16).

\section{MATERIALS AND METHODS}

The study was conducted at the Nairobi juvenile court, Kenya. Authority to conduct research was obtained from the Office of the President. As all the children and young persons in this study were below the age of 18 years, consent for interviewing them was requested from the Office of the President. The relevant protocol through the Permanent Secretary, Ministry of Home Affairs, the Registrar of Courts, the Director of Children's Department and the Director of Probation was followed to enable one of the researchers to be present in the juvenile court and to be assisted by the probation officers and children's officers. In criminal offenders, every third child or young person who appeared on the court register during, the study period was interviewed and designated as Group 1. All children and young persons appearing in the court for protection and discipline during the study period were interviewed and designated as Group 11.

A socio-demographic questionnaire was first administered followed by the Reporting Questionnaire for Children (RQC). The latter was to screen for psychiatric morbidity. Children scoring one or more than one positive answer (RQC positive) were subjected to the second stage of screening; the Followup Interview for Children (FIC). Psychiatric diagnosis was assigned according to the ICD-10. Data analysis was done by a computer using the Statistical Package for Social Sciences (SPSS) Version 8.0 and a probability value of equal or less than $0.05(\mathrm{P} \leq 0.05)$ was taken to be statistically significant.

\section{RESULTS}

Psychiatric morbidity: In this study a CPM of 40 out of $90(44.4 \%)$ children and young persons was obtained. Among those with PM, 26 (65\%) were males and $14(35 \%)$ were females.

Sample size - Group $1=60$ males -45 females -15

$$
\mathrm{M}: \mathrm{F} \quad-\quad 3: 1
$$

Group 11 = 30 males -19 females - 11

$$
\begin{array}{ll}
\mathrm{N}=90 \quad \mathrm{~F}-1.7: 1 \\
& \text { males }-64 \text { females }-26 \\
& \mathrm{M}: \mathrm{F}-2.5: 1
\end{array}
$$

Males with PM

- (a) Group I- 17(28.9\%)

- (b) Group II - 9(30\%)

Females With PM

- (a) Group 1- 6 (10\%)

- (b) Group $118(26.6 \%)$

Of the PM samples

$$
\begin{aligned}
& \text { - Group } 1 \text { M:F - 3:1 } \\
& \text { - Group II M:F - 1.1:1 }
\end{aligned}
$$

Socio-demographic factors: Children and young persons included in this study were all between 8-18 years. The total sample size was 90 . Those in the age group $\leq 12$ years were 26 (28.7\%), 13-15 years were $47(52.2 \%)$ and $16-18$ years were $17(18.9 \%)$. 
In the age group $\leq 12$ years, PM was found in 10 out of the 90 children (11. 1\%) and comprised five $(8.5 \%)$ males and two (34\%) females of the 60 children in group 1 whereas $(6.7 \%)$ males and one (3.3\%) female were from group consisting of 30 children.

In the age group 13-15 years, PM was found in 20 out of the total 90 children $(22.2 \%)$ and comprised of eight (13.6\%) males and two (3.4\%) females of the 60 children in group I whereas four $(13.3 \%)$ males and six $(20 \%)$ females were part of the 30 children in group II.
In the age group 16-18 years, PM was found in 10 out of the total 90 children $(11.1 \%)$ and comprised of four $(6.8 \%)$ males and two $(3.4 \%)$ females of the 60 children in group I whereas three $(10 \%)$ males and one $(13 \%)$ female came from the 30 children in group II, (Table 3)

Deviant behaviours: A variety of deviant behaviours were reported in this study. The common deviant behaviours were premature leaving of school, substance use, running away from home, begging, problems with parents, problems with peers, stealing, thefts and robberies (Table 4).

Table 2

Psychiatric disorders detected

\begin{tabular}{|c|c|c|c|c|c|c|c|}
\hline \multirow[t]{2}{*}{$\begin{array}{l}\text { ICD-10 } \\
\text { Code }\end{array}$} & \multirow[t]{2}{*}{ Diagnosis } & \multirow{2}{*}{$\begin{array}{c}\text { Count } \\
\text { Row \% } \\
\text { Column \% } \\
\text { Total \% }\end{array}$} & \multicolumn{2}{|c|}{$\begin{array}{l}\text { Group I } \\
\mathrm{N}=60\end{array}$} & \multicolumn{2}{|c|}{$\begin{array}{l}\text { Group II } \\
\mathrm{N}=30\end{array}$} & \multirow[t]{2}{*}{$\begin{array}{l}\text { Total } \\
\mathrm{N}=90\end{array}$} \\
\hline & & & M & $\mathrm{F}$ & M & $\mathrm{F}$ & \\
\hline \multirow[t]{4}{*}{ F 91} & \multirow{4}{*}{\multicolumn{2}{|c|}{ Conduct Disorders }} & 8 & 2 & 5 & 3 & \\
\hline & & & 44.0 & 11.0 & 27.5 & 16.5 & \\
\hline & & & 47.2 & 33.4 & 55.5 & 37.5 & 18 \\
\hline & & & 20.0 & 5.0 & 12.5 & 7.5 & $(45 \%)$ \\
\hline \multirow[t]{4}{*}{ F 92} & \multirow{4}{*}{\multicolumn{2}{|c|}{$\begin{array}{l}\text { Mixed Disorders of } \\
\text { Conduct and Emotions }\end{array}$}} & 3 & 0 & 3 & 2 & \\
\hline & & & 37.5 & 0.0 & 37.5 & 25.0 & \\
\hline & & & 17.5 & 0.0 & 33.3 & 25.0 & 8 \\
\hline & & & 7.5 & 0.0 & 7.5 & 5.0 & $(20 \%)$ \\
\hline \multirow[t]{4}{*}{ F93 } & \multirow{4}{*}{\multicolumn{2}{|c|}{$\begin{array}{l}\text { Emotional Disorders with onset } \\
\text { specific to childhood }\end{array}$}} & 1 & 3 & 1 & 3 & \\
\hline & & & & 12.5 & 37.5 & 12.5 & 37.5 \\
\hline & & & 5.9 & 51.1 & 11.1 & 37.5 & 8 \\
\hline & & & 2.5 & 7.5 & 2.5 & 7.5 & $(20 \%)$ \\
\hline \multirow[t]{4}{*}{ F30-F39 } & \multirow{4}{*}{\multicolumn{2}{|c|}{ Mood Disorders }} & 4 & 1 & 0 & 0 & \\
\hline & & & 80.0 & 20.0 & 0.0 & 0.0 & \\
\hline & & & 23.6 & 16.7 & 0.0 & 0.0 & \\
\hline & & & 10.0 & 2.5 & 0.0 & 0.0 & 5 \\
\hline \multirow[t]{5}{*}{ F 90} & \multirow{4}{*}{\multicolumn{2}{|c|}{ Hyperkinetic Disorder }} & 1 & 0 & 0 & 0 & $(12.5 \%)$ \\
\hline & & & 100.0 & 0.0 & 0.0 & 0.0 & \\
\hline & & & 5.9 & 0.0 & 0.0 & 0.0 & 1 \\
\hline & & & 2.5 & 0.0 & 0.0 & 0.0 & $(2.5 \%)$ \\
\hline & \multicolumn{2}{|l|}{ Total } & $\begin{array}{c}17 \\
(42.5 \%)\end{array}$ & $\begin{array}{c}6 \\
(15.0 \%)\end{array}$ & $\begin{array}{c}9 \\
(22.5 \%)\end{array}$ & $\begin{array}{c}8 \\
(20 \%)\end{array}$ & $\begin{array}{c}40 \\
(100 \%)\end{array}$ \\
\hline
\end{tabular}

Group I + Group II- $\mathrm{X}^{2}=9.53 ; \mathrm{DF}=5 ; \mathrm{P}=0.0897 \mathrm{NS}$

Group I $-\mathrm{X}^{2}=6.23 \mathrm{DF}=4 ; \mathrm{P}=0.182 \mathrm{NS}$

Group II - Statistical analysis was not done due to the high number of zeros

1. Findings not statistically significant

2. $\mathrm{PM}$ ratio in $\mathrm{M}: \mathrm{F}$ in group $\mathrm{I}$ is $2.8: 1$

3. $\mathrm{PM}$ ratio in $\mathrm{M}: \mathrm{F}$ in group II is $1.1: 1$ 
Table 3

Age vs. psychiatric morbidity

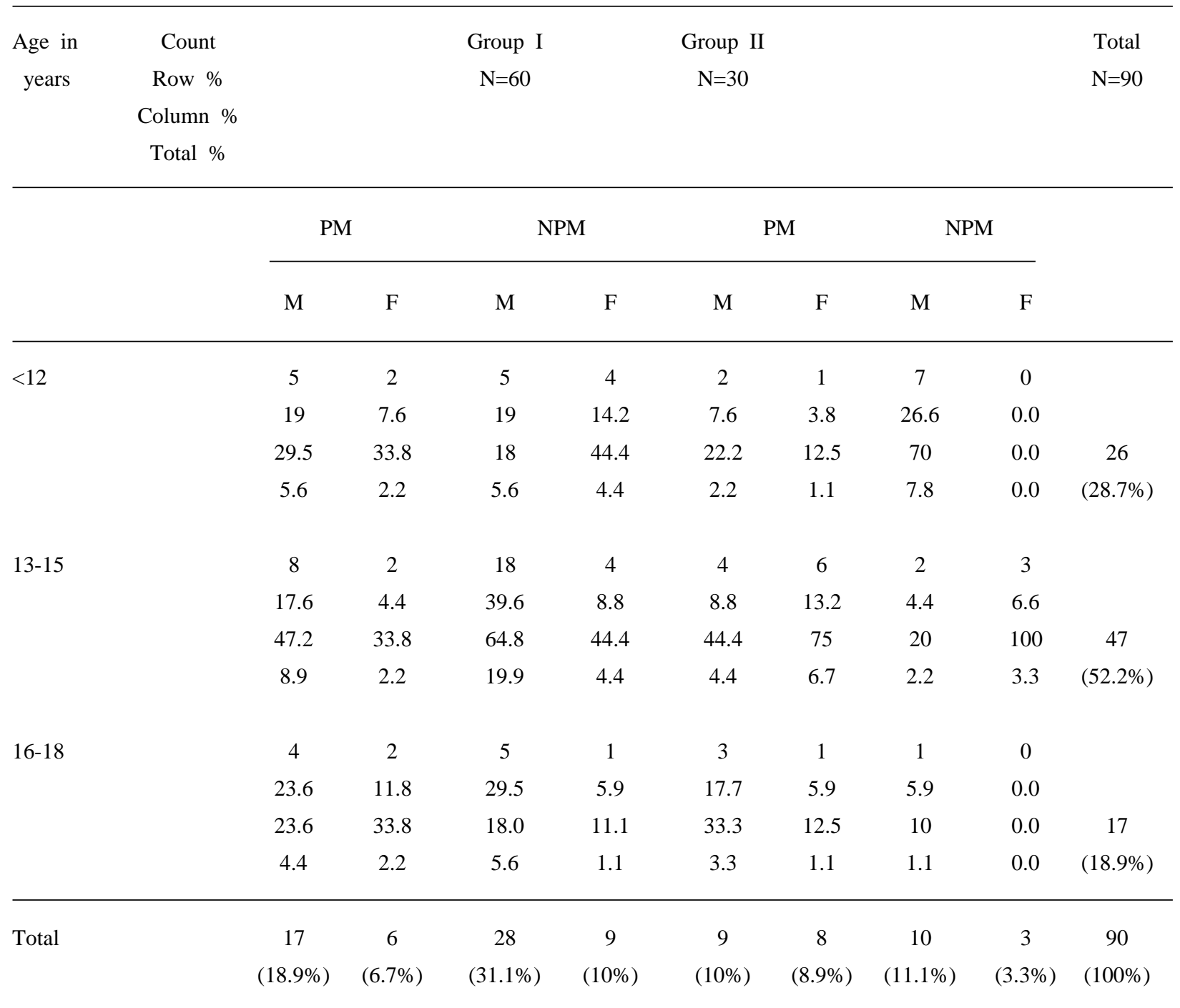

$\begin{array}{lccc}\text { Group I + Group II }-\mathrm{X}^{2}=15.46 & \mathrm{DF}=10 & \mathrm{P}=0.116 \mathrm{NS} \\ \text { Group I }-\mathrm{X}^{2}=14.4 & \mathrm{DF}=10 & \mathrm{P}=0.158 \mathrm{NS} \\ \text { Group II }-\mathrm{X}^{2}=7.4 & \mathrm{DF}=6 & \mathrm{P}=0.286 \mathrm{NS}\end{array}$

1. Findings statistically not significant

2. Children ( $\leq 12$ years) were $28.7 \%$

3. Adolescents (13-18 years) were $71.3 \%$

4. Crude mean age (all children) $=13.7$ years

5. Crude mean age for all males $=13.8$ years

6. Crude mean age for all females $=13.7$ years

7. Mean age of males with $\mathrm{PM}=13.4$ years

8. Mean age of females with $\mathrm{PM}=13.4$ years 
Table 4

Deviant behaviour vs psychiatric morbidity

\begin{tabular}{|c|c|c|c|c|c|c|c|c|c|}
\hline \multirow[t]{3}{*}{ Deviant behaviour } & \multicolumn{4}{|c|}{$\begin{array}{c}\text { Group I } \\
\mathrm{N}=60\end{array}$} & \multicolumn{4}{|c|}{$\begin{array}{c}\text { Group II } \\
\mathrm{N}=30\end{array}$} & \multirow[t]{3}{*}{$\begin{array}{l}\text { Total } \\
\text { Freq. }\end{array}$} \\
\hline & \multicolumn{2}{|c|}{ PM } & \multicolumn{2}{|c|}{ NPM } & \multicolumn{2}{|c|}{$\mathrm{PM}$} & \multicolumn{2}{|c|}{ NPM } & \\
\hline & M & $\mathrm{F}$ & M & $\mathrm{F}$ & M & $\mathrm{F}$ & M & $\mathrm{F}$ & \\
\hline Left school & 16 & 6 & 24 & 7 & 6 & 4 & 9 & 3 & 75 \\
\hline Substance use & 13 & 2 & 12 & 1 & 7 & 3 & 1 & 0 & 39 \\
\hline Running away from home & 16 & 2 & 6 & 2 & 3 & 2 & 0 & 0 & 31 \\
\hline Begging & 10 & 3 & 15 & 2 & 0 & 0 & 0 & 0 & 30 \\
\hline Problems with parents & 7 & 3 & 2 & 0 & 4 & 5 & 1 & 0 & 22 \\
\hline Stealing/thefts/robberies & 5 & 0 & 5 & 0 & 0 & 0 & 0 & 0 & 10 \\
\hline Problems with peers & 5 & 0 & 2 & 0 & 0 & 1 & 1 & 0 & 9 \\
\hline Problems with teachers & 1 & 0 & 1 & 0 & 2 & 1 & 0 & 0 & 5 \\
\hline Problems with members of public & 0 & 3 & 0 & 1 & 0 & 1 & 0 & 0 & 5 \\
\hline Problems with police/administration & 1 & 0 & 2 & 0 & 0 & 0 & 0 & 0 & 3 \\
\hline Problems with siblings & 0 & 0 & 0 & 1 & 1 & 0 & 0 & 0 & 2 \\
\hline Sexual abuser (rapist) & 1 & 0 & 0 & 0 & 0 & 0 & 0 & 0 & 1 \\
\hline Possession of drugs & 0 & 0 & 3 & 0 & 0 & 0 & 0 & 0 & 3 \\
\hline Sexually active & 2 & 2 & 0 & 1 & 1 & 0 & 0 & 0 & 6 \\
\hline Suicide attempt & 0 & 1 & 0 & 0 & 0 & 1 & 0 & 0 & 2 \\
\hline Total & 77 & 22 & 72 & 15 & 24 & 18 & 12 & 3 & 243 \\
\hline
\end{tabular}

1. Due to the large number of zeros, statistical significance was not evaluated

2. The table shows multiple deviant behaviours

\section{DISCUSSION}

This study consisted of 90 children and young persons, formed of 60 offenders (Group I) and 30 others (Group II) in need of discipline and protection. It was found that 40 out of the $90,(44.4 \%)$, children and young persons in the whole sample had a psychiatric diagnosis. These 40 consisted of $26(65 \%)$ males and $14(35 \%)$ females. Of these forty, $23(57.5 \%)$ were from group 1 and $17(42.5 \%)$ were from group II.

Of the 23 from group I, 17 (74\%) were males and six $(26 \%)$ were females. Of the 17 from group II, nine $(52.8 \%)$ were males and eight $(47.2 \%)$ females (Tables 2 and 3 ).

The CPM prevalence rate in this study (44.4\%) was much higher than in findings by other researchers in the Kenyan settings(17-20). A study among 85 children and young persons admitted into an approved school in Nairobi found a PM prevalence rate of $24.8 \%(17)$. This prevalence could possibly have been low as a result of the influence of living in the approved school which would have strict rules and regulations.
In a study of 303 children (164 boys, 139 girls) aged between 5-15 years, attending a primary health care facility in a suburban township in Nairobi, a CPM prevalence rate of $20 \%$ using the RQC and FIC was reported (18). A study among 78 children (37 males, 41 females) aged between $8-18$ years, in a communitybased institution in Nairobi around a PM prevalence rate of $41 \%$ using the RQC and FIC(19). In a comparative study of psychiatric morbidity in rural and urban primary school pupils in Kenya found the crude $\mathrm{PM}$ rates to be $26.4 \%$ (rural) and $41.2 \%$ (urban) using the RQC and FIC(20). Minde(21) found that 18-24\% psychiatric morbidity was present among Ugandan primary school children.

(i) Conduct disorders: Out of the total sample of 90 children, $18(20 \%)$ had conduct disorders and were composed of $13(14.4 \%)$ males and five $(5.6 \%)$ females. Out of these eighteen, $10(55.6 \%)$ were from group I and eight (44.4\%) from group II. Of the 10 from group 1 , eight $(80 \%)$ were males and two $(20 \%)$ were females. Of the eight from group II five $(62.5 \%)$ were males 
and three $(37.5 \%)$ were females. The crude MS ratio for conduct disorders was 2.6:1 (group I, 4:1; group II, 1.7: 1). This shows that conduct disorders are more common in males than females in both groups but more so among males of group I.

Rates for conduct disorders among children from other African countries have been reported as follows; from Ghana 3\% (22), from Nigeria 5.5\% (23) and (24)10\%. from Uganda (21)14\%. In the Isle of Wight study (II), nearly two thirds of the 10-11 year old with psychiatric disorders were found to have conduct disorders. Including the children with mixed neurotic and conduct disorders, the prevalence of conduct problem was $4 \%$.

(ii) Mixed disorders of conduct and emotions: Out of the total sample of 90 children, eight (8.9\%) had mixed disorders of conduct and emotions and were composed of six $(6.7 \%)$ males and two $(2.2 \%)$ females. Out of these eight, three $(37.5 \%)$ were from group 1 and five $(62.5 \%)$ from group II. From group I, all three (100\%) were males. Of the five from group 11 , three $(60 \%)$ were males and two (40\%) females. The crude male female ratio for mixed disorders of conduct and emotions was 3:1 (group 1:3:0 and 1:5:1 for group II). This suggests that mixed disorders of conduct and emotions are more common in males than females in both groups.

Mwangi (20) in his study reported $13.2 \%$ of pupils from a rural primary school and $5.6 \%$ of pupils from an urban primary school with mixed disorders of conduct and emotions. Rutter et al. (11) reported that it is relatively common for children and adolescents with deviant behaviour, and especially those with more widespread conduct disorders, to show emotional disturbances. He further states that the pattern of changing symptomatology between middle childhood and adolescence may show a good deal of shift from conduct disorders to mixed disorders.

(iii) Emotional disorders with onset specific to childhood: Out of a total sample of 90 children, eight $(8.9 \%)$ had emotional disorders with onset specific to childhood and were composed of two $(2.2 \%)$ males and six $(6.7 \%)$ females. Of these eight, four $(50 \%)$ were from group 1 and four $(50 \%)$ were from group II.

Of the four from group I, one $(25 \%)$ was a male and three $(75 \%)$ were females. Of the four from group II, one $(25 \%)$ was a male and three $(75 \%)$ were females. The male:female ratio being 1:3 for both groups. Hence emotional disorders with onset specific to childhood were more common in females than males.

(iv) Mood disorders: Out of the total sample of 90 children, five $(5.6 \%)$ had mood disorders and were composed of four males $(4.4 \%)$ and one female $(1.1 \%)$. All these five children were from group I and consisted of four males $(80 \%)$ and one female $(20 \%)$
. Among the four males who suffered from mood disorders, three $(75 \%)$ had features of depression and one $(25 \%)$ had hypomania. The only female with a mood disorder had depression, a history of one suicide attempt and had been sexually molested twice.

In the Isle of Wight study(11), $13 \%$ of the children studied at the age of 10 years showed depressed mood at interview, $17 \%$ failed to smile and $15 \%$ showed poor emotional responses. At 14-15 years of age, over $40 \%$ reported feelings of misery and depression, $20 \%$ described feelings of self-depreciation, $7 \%$ reported suicidal feelings and $25 \%$ had ideas of reference.

(v) Hyperkinetic disorder: This disorder was found only in one male from group I. A study among boys on probation, in Canada, reported that those who were hyperactive tended to be more antisocial(25).

\section{CONCLUSIONS}

This study showed a high prevalence of morbidity (44.4\%), and 15 different types of deviant behaviours by the children and young persons appearing in the Nairobi juvenile court. These children and young persons definitely need urgent psychological and psychiatric management as stipulated in Section 18, CAP 141 of The Laws of Kenya. The Children's and Young Persons Act states "if it appears to the court on the evidence of a medical practitioner that a child or young person, although not of unsound mind, requires or may benefit from mental treatment the court when making a probation order against him, may require him to undergo mental treatment at the hands or under the direction of a medical practitioner for a period not exceeding twelve months, subject to review by the court, as a condition of the probation order."

\section{RECOMMENDATIONS}

Probation and Children Department officials require more training in the field of psychiatry so as to be able to identify psychiatric morbidity in children on first contact. This will enable them to adequately advise the court in the proper referral of such cases for further psychiatric assessment and treatment as necessary.

The Juvenile court officers (Judiciary, Prosecution, Probation and Children Officers) should be more sensitised to recognise psychopathology more readily and dispose these cases, when and where indicated, as prescribed by relevant statutes for specialised psychiatric assessment and management.

Forensic psychiatric input in the juvenile courts should be more regularly provided by qualified psychiatric personnel assigned to the court in order to screen for PM in the children and young persons prior to disposal of the cases by courts. The aim should be 
the benefits acheived from mental treatment and not just on the "soundness of mind" of the children appearing in the said court as per Section 18 of CAP 141. This screening process shall assist in decongesting the juvenile court by expediting the disposal of the mentally disordered children and young persons.

Children with delinquent behaviour and history of substance use should be identified in the school years and placed into community-based programmes which should include vocational training, increased recreational activities, teaching and enhancement of good social skills as well as life philosophy and theology so as to pre-empt maladjustment.

Court appearances with suspended sentence, as a deterrent to deviant behaviour should be introduced.

Juvenile courts should be transformed into Family Courts in order to effectively execute court recommendations affecting in-community rehabilitation.

\section{FURTHER RESEARCH}

Since this was a point prevalence study, longitudinal studies could be done by assessing PM at the juvenile court and then changes of PM in the same population, over a period of time. This may involve institutional and community-based longitudinal studies of such study population groups.

A high percentage of PM $(44.4 \%)$ was found in this study, it is hereby recommended that a research on the prevalence of PM among children and young persons who are living in the streets as their natural habitat be conducted in order to further elucidate the degree and pattern of PM in the deviant youth in Kenya.

\section{ACKNOWLEDGEMENTS}

To all members of staff of the Probation and Children's Departments, Ministry of Home Affairs, Nairobi, Kenya for their undeniable assistance during this study. This work was in part financed by $\mathrm{m} / \mathrm{s}$ Solvay Pharma through Phillips Pharmaceuticals Limited, Kenya.

\section{REFERENCES}

1. Russel, D.H. Juvenile delinquency. Psychiatry Annal. 1975; 5:3-13.

2. Robbins, L. Deviant children grown up. The Waverly Press Inc., Baltimore. 1966.

3. Kaplan, H.I., Saddock, B.J. and Grebb, J.A. Synopsis of Psychiatry 7th Edition. Williams and Wilkins, Baltimore, 1994.
4. Lucien, B. Psychiatric aspects of child delinquency. Bulletin World Health Org. 1957; 3: 63-162.

5. Snyder, C. Future child. Winter. 1996; 3: 140-146.

6. Torome, S.T. Delinquent child in proceedings of Kenya Paediatric Association Scientific Seminar. UNICEF/ Government of Kenya, 1985.

7. Christiansen, K.O. A Preliminary study of criminality among twins. Biosocial basis of criminal behaviour. Gardener Press New York. 1977; 89-108.

8. Alm, P., Klinteberg, B., Humble, K. et al. Psychopathy, Platelet MAO activity and criminality among former juvenile delinquents. Acta Psychiatr. Scand (Denmark). 1996; 94: 105-111.

9. Eysenck, H.J. Crime and personality. Routledge and Kegan Paul, 3rd Edition: London. 1964.

10. Gelder, M., Gath, D. and Mayuo, R. Oxford textbook of psychiatry. 2nd Edition. Oxford University Press, Oxford. 1993.

11. Rutter, M., Tizard, J. and Whitmore, K. Education, Health and Behaviour. Longmans - London. 1970.

12. Bond, M.R. The psychiatry of closed head injury. Oxford University Press: Oxford, 1984.

13. Ferguson, D.M., Lyriskey, M.T. and Horwood, L.J. ChristChurch Health and Development Study. New Zealand. J. Child Psych/Psychiat. 1997; 24: 533-553.

14. Treiman, D.M. and Delgado-Escueta, A.V. Violence and epilepsy: A critical reviev." Recent Advances in Epilepsy. 1983; 1: 38-43.

15. West, D.I. and Farrington, D.P. Who becomes delinquent? Heinemann: London, 1973.

16. The children and young persons Act (1963). Laws of Kenya Chapter 141. The Kenya Gazette. 1963; Vol. VIII, Supp. 8: $73-118$,

17. Gatangi, A.S.M. Psychiatric morbidity in children and young persons admitted into an approved school in Nairobi. MMed (Psych.) Dissertation U.o.N., 1987.

18. Kang'ethe, R.N. The frequency, pattern and recognition of childhood psychiatric morbidity among children attending Kawangware Health Centre. MMed (Psych.) Dissertation, U.o.N., 1988.

19. Mwangi, S. Psychiatric morbidity among children in Undugu Society of Kenya Homes. MMed (Psych.) Dissertation, U.o.N., 1996.

20. Mwangi, N. A comparative study of psychiatric morbidity in rural and urban primary school students. MMed (Psych.) Dissertation, U.o.N., 1996.

21. Minde, K. Child psychiatry in developing countries. J. Child Psych. Psych. 1976; 17: 79-83.

22. Adamakoh, C.C. The disturbed child in Ghana. paper presented at the Association of Psychiatrists in Africa Workshop. 1973.

23. Izuora, G.E.A. Mental health of children in developing countries. Proceedings, 2nd Pan African Psychiatric Workshop, Mauritius. 1970.

24. Olatawura, M.O. Child Psychiatric Disorders in IbadanNigeria. Nigeria J. Paediatrics. 1976; 3: 9.

25. Rutter, M. and Giller, H. Juvenile delinquency - trends and perspectives. Penguin Publication, Middlesex, 1983. 